\title{
Patologi Kekerasan dalam Berita Televisi: antara Kontroversi dan Regulasi
}

\author{
SANTI INDRA ASTUTI \\ Fakultas IImu Komunikasi, Universitas Islam Bandung, JI. Tamansari No.1 Bandung 40116 \\ email: dyaning2001@yahoo.com
}

\begin{abstract}
Indonesia television journalism is growing rapidly, yet, a close observation has revealed a domination of violence as reflected in its content. Violence even became a kind of appeal to seduce audience and influence them to watch the whole teather of media violence. I gnoring this circumstance will led to a huge sacrifice. Studies concerning mass media impact have showed range of influences between violence content and audience's mental state of health. In order to control the violence on journalism television, a strict law enforcement must be perpetrated. But, to do so, several arguments often recited by media in order to prevent law enforcement efforts must be identified and be replied in most sophisticated fashion by preparing ellegant counter arguments.
\end{abstract}

Keywords: media violence, news, journalism television, broadcast regulation

\begin{abstract}
Abstrak. Tayangan jurnalisme di televisi Indonesia saat ini didominasi oleh unsur kekerasan. Kekerasan bahkan dijadikan semacam daya tarik untuk memancing penonton agar menyaksikan tayangan berita sampai selesai. Apabila diabaikan, hal ini sangat berbahaya. Kajian seputar dampak kekerasan di media terhadap penonon menunjukkan adanya pengaruh langsung maupun tidak langsung antara tayangan kekerasan dengan penonton. Upaya menangkalnya perlu dimulai dari penegakan regulasi penyiaran guna mengontrol kekerasan di media. Untuk itu, sejumlah dalih yang biasa dilontarkan media untuk menghindari regulasi tersebut harus diidentifikasi dan dicari landasan counter-argumentnya.
\end{abstract}

Kata Kunci: kekerasan di media, berita, jurnalisme televisi, regulasi penyiaran

\section{Pendahuluan}

Dalam medium layar kaca, alias televisi, kekerasan menjadi bagian dari praktik jurnalisme yang dianggap paling nyata dan 'menjual'. Bahkan, ada kecenderungan bahwa berita-berita kriminal yang ditayangkan televisi Indonesia saat ini telah dijadikan etalase bagi khalayak, sengaja ditempatkan sebagai pembuka program bak headline dalam surat kabar, agar pemirsa tertarik mengikuti program berita secara penuh (Williams, 2009: 181; Mulkan, 2011: 3).

Dalam ranah kajian media, mengurai kekerasan satu demi satu dalam tayangan televisi sendiri merupakan pekerjaan yang time-consuming. Kekerasan telah merasuk nyaris di setiap program, baik tayangan faktual seperti berita, reality show, dokumenter dan talkshow, hingga tayangan non faktual seperti komedi, drama, dan iklan. Kekerasan dalam media, karenanya, sudah menyebar ke mana-mana, dan meracuni baik stasiun televisi maupun pemirsanya. I nilah patologi kekerasan-yaitu, ketika kekerasan menjadi wabah penyakit yang tak tersembuhkan. Wabah ini tak terlihat, namun, menjadi bahaya laten yang membuat media seperti televisi di Indonesia menjadi semacam virus yang perlu dijauhi. Setidaknya, untuk saat ini.

Bertitik tolak dari kondisi sedemikian, sejumlah pertanyaan menjadi landasan bagi penulisan artikel ilmiah ini. Pertama, bagaimanakah sesungguhnya wajah atau tampilan kekerasan di media, khususnya televisi, pada umumnya? Kedua, dilema macam apa yang dihadapi oleh para regulator yang berusaha menegakkan regulasi seputar tayangan kekerasan di media? Ketiga, solusi apa saja yang bisa ditawarkan guna mengatasi hal tersebut. Sebagai sebuah kajian konseptual, materi-materi dalam tulisan ini dilacak melalui studi pustaka. Melalui tulisan ini, diharapkan akademisi khususnya, maupun publik pada umumnya, menjadi kian terbuka pemahamannya dalam menyaksikan dan mengkritisi tayangan berita televisi bermuatan 
kekerasan. Sehingga, dapat mendukung upaya advokasi membersihkan media dari kandungan kekerasan yang berlebihan.

\section{Kekerasan: Orientasi J urnalisme Televisi Pasca Reformasi}

Pada 1994, rata-rata, stasiun televisi yang bersiaran secara nasional di Indonesia memiliki porsi tayangan berita kurang lebih sebanyak $30 \%$. Siaran berita TVRI mencapai $36.71 \%$, RCTI sebnyak $28.42 \%$, MNC sebanyak $24.12 \%$, SCTV sebesar $35.28 \%$, sementar AnTV sebesar 27.27\%. Inilah hasil penelitian Ishadi SK, mantan direktur Trans TV dan TVRI, yang dipublikasikan secara resmi (Mulkan, 2011: 2). Hingga kini, porsi berita di stasiun-stasiun televisi tadi tidak banyak berubah. Saat ini, sebuah stasiun televisi pada umumnya memiliki 3 segmen penayangan berita setiap hari, dengan durasi mencapai 30 menit (Susanti, dalam Junaedi, 2011:281). Maka, bisa diperkirakan seberapa besar persentase tayangan berita yang muncul di layar kaca. Porsinya tampaknya tak beranjak dari angka 30\%, bahkan mungkin jauh lebih kecil jika berita-berita yang terkategori filler atau sisipan dikeluarkan dari komposisi ini. Yang jelas, berita jurnalisme 'asli' ini lebih sedikit porsinya dibanding berita-berita infotainment yang mengaku-aku sebagai bagian dari praktik jurnalisme.

Kondisi berbeda dialami oleh Metro TV dan Tvone. Kedua stasiun televisi memiliki porsi pemberitaan yang jauh lebih besar. Tidak heran, karena baik Metro TV maupun TvOne sama-sama mengklaim diri sebagai televisi berita. Selama beberapa tahun, kedua stasiun dengan sukses telah mem-branding dirinya sebagai ikon jurnalisme televisi Indonesia. Sehingga, dalam benak penonton Indonesia, tidak ada stasiun TV lain yang lebih tepercaya dan dapat diandalkan dalam soal jurnalisme ketimbang kedua stasiun televisi tadi.

Porsi program bermuatan berita (news) sepanjang weekdays di Metro TV sebanyak 60\%, sementara pada weekend menjadi $40 \%$. Untuk TvOne, porsi berita mencapai $70 \%$ setiap hari, terdiri dari hard news dan feature news (misalnya, dokumenter, talk show, dll). Berbeda dengan televisi swasta bersiaran nasional lainnya, kedua stasiun televisi berani menyiarkan berita sepanjang 1 jam dalam setiap program unggulannya, yang ditayangkan sedikitnya 3 kali sehari. Ini belum termasuk filler-filler yang disisipkan di berbagai program.

Kondisi sedemikian tidak lantas menjadikan praktik jurnalisme televisi menjadi berkualitas. Sama halnya dengan tayangan televisi lainnya, program jurnalisme pun dikendalikan oleh rating dan share. Rating menunjukkan persentase penonton di antara keseluruhan populasi penduduk yang menonton sebuah acara pada satu waktu. Sementara share adalah persentase penonton yang menyaksikan sebuah acara di antara para penonton lain yang menyaksikan televisi pada jam atau rentang waktu yang sama (Panjaitan \& I qbal, 2006: 82-83). Rating dan share menjadi tolok ukur penayangan program, sekaligus menentukan peta program dalam sebuah pasar atau industri media massa, dalam hal ini, televisi. Demi meraih rating dan share yang tinggi, setiap stasiun televisi berlomba-lomba untuk menayangkan program berita yang seru dan sensasional. Nilai kebenaran menjadi tersisih, digantikan oleh hasrat untuk mengeksploitasi emosi manusia-dalam hal ini, penonton. Maka, jurnalisme yang seharusnya berorientasi pada kepentingan publik, dengan mudah berbalik orientasi menjadi lebih terfokus pada pasar. Ketika jurnalisme menjadi bagian dari pasar, maka, sebagaimana pasar lainnya, pedagang harus memoles dan mengemas dagangannya sedemikian rupa, sehingga banyak 'konsumen' yang tertarik untuk membeli, alias menonton tayangannya. Mari kita cermati apakah kondisi sedemikian juga terjadi dalam konteks pemberitaan di televisi.

Pengamatan terhadap praktik jurnalisme televisi Indonesia memperlihatkan, sejak 1998, tatkala situasi politik nasional memanas hingga berpuncak pada terjadinya Reformasi, tayangan berita mengalami booming luarbiasa. Publik menanti-nanti tayangan berita, dan jurnalis televisi menjadi selebriti baru di layar kaca. Berita yang mendominasi pada era tersebut adalah beritaberita seputar panasnya situasi poltik nasional.

Tahun 2000-an, ketika Reformasi mulai berjalan, berita kriminal mengambil tempat. Dan menjadi primadona baru di layar kaca. Penonton tampaknya juga menyukai, ini terlihat dari indikator rating program berita yang mencapai poin 7 . J elas, fenomena tersebut merupakan prestasi luarbiasa, sebuah angka yang jarang diperoleh tayangan televisi semacam program berita. Sejak itulah, stasiun televisi mulai mengemas program-program jurnalisme bermuatan kekerasan, karena menyadari potensi ekonomi yang bisa dieksploitasi (Mulkan, 2011: 34). Maka, tidak salah jika dikatakan bahwa kekerasan telah menjadi komoditas baru di layar kaca. Litbang Kompas dalam kajiannya seputar tayangan televisi mendapati bahwa sejak 2011, program berita televisi di tanah air telah memiliki tempat di tengah masyarakat. Program berita bahkan bisa mengalahkan tayangan sinetron, yang sebelumnya menjadi favorit pemirsa di berbagai stasiun televisi (Mulkan, 2011: 2). Bertambah lagi, dengan demikian, alasan untuk menjadikan berita televisi sebagai salah satu unggulan untuk dijajakan di tengah pemirsa.

Namun, seperti telah diungkap sebelumnya, 
ada harga mahal yang harus dibayarkan untuk semua ini. Kekerasan, dalam porsi seberapapun, senantiasa mengundang korban dalam berbagai level. Riset-riset seputar kekerasan media mengungkap cerita horor di balik maraknya tayangan kekerasan di media yang begitu berpengaruh di tengah publik, seperti televisi.

\section{Riset-riset Seputar Kekerasan di Media}

Penelitian Gerbner (1972) memperlihatkan, program prime time TV mengandung sedikitnya 8 adegan kekerasan. Penelitian Gerbner yang lebih mutakhir (1986) memperlihatkan, adegan kekerasan muncul setiap 4 menit, baik dalam reality show, drama TV, siaran dokumenter, maupun pemberitaan. Kemungkinan, frekuensi dan selang pemunculan kekerasan kini lebih sering lagi terlebih dengan berkembangnya genre-genre program baru di media, seperti cops drama (campuran genre drama dan suspense thriller bertema hukum dan kinerja aparat penegak hukum, seperti NYPD Blue, CSI, Criminal Minds, atau NCIS) dan hororreligi (campuran genre drama bertema religi dan suspense thriller seperti Rahasia Ilahi, Azab, Tobat, dan lain-lain). Riset Gerbner memang semata berfokus pada muatan kekerasan di dalam media-persoalan content. Walaupun hanya terkonsentrasi pada muatan atau isi media, data Gerbner cukup mengejutkan. Jika muatannya saja sudah begitu kental dengan unsur-unsur kekerasan, maka, bagaimana dampaknya di tengah masyarakat yang tidak sedikit menontonnya secara teratur?

Riset klasik terkenal lain yang patut dikutip seputar kekerasan media dilakukan pada 1960an, hingga menghasilkan The Surgeon's General Report. Riset ini menjadi penting karena dilakukan di tengah turbulensi media Amerika Serikat 1960an, ketika tingkat kekerasan dan kriminalitas di AS meningkat tajam dan cukup banyak pemimpin dunia yang menjadi korban kekerasan. Riset ini merekomendasikan gagasan bahwa menonton media violence dalam kadar tertentu meningkatkan kemungkinan perilaku agresif (Perry, 2002: 228).

Terlepas dari pro-kontra seputar hasil dan metodologi riset-riset kekerasan media, kajiankajian mutakhir seputar efek kekerasan media di seluruh dunia menyiratkan bahwa pantulan kekerasan media memiliki efek langsung mau pun tak langsung pada khalayaknya. Eron \& Huesmann (1984) bahkan berani menyimpulkan bahwa anak yang diterpa adegan kekerasan media “... as early as 8 years old, predicts the seriousness of crimes committed by age 30 among both US females and males" (Perry, 2002:231).

Kebenaran dari pernyataan Eron \& Huesmann sulit dibantah. Pasalnya, mereka melakukan kajian longitudinal yang luarbiasa cermatnya terhadap 800 anak yang menjadi sampelnya. Pada tahun 1960, anak-anak yang masih berusia 8 tahun ini diteliti. Sebelas dan 22 tahun kemudian, penelitian ini diulangi kembali untuk mengukur kadar agresifitas sampelnya, yang tentunya sudah menjadi remaja, lantas dewasa. Hasilnya, anak-anak yang agresif menjadi jauh lebih agresif ketika mencapai usia remaja dan dewasa. Mereka membuat masalah yang lebih besar, mulai dari melakukan KDRT hingga melakukan pelanggaran lalu lintas, dibandingkan rekan mereka yang tidak seberapa agresif karena tidak sebanyak kelompok pertama yang menonton kekerasan di televisi. Bagi Eron dan Huesmann, menonton kekerasan di TV merupakan faktor yang paling dekat hubungannya dengan perilaku agresif, melebihi kemiskinan, ras, atau model perilaku orangtua (Chen, 2005: 59).

Soal pengaruh kekerasan pada media yang berdampak pada timbulnya perilaku agresif, kembali diteliti oleh Halloran pada tahun 1970. Melalui kajian eksperimental, Halloran menyimpulkan bahwa 'menonton kekerasan di media massa' (the observation of mass media violence) mungkin, meski tidak mendeterminir, merupakan suatu faktor bagi munculnya perilaku agresif (Williams, 2009: 168).

Mengapa media dapat berkontribusi pada perilaku agresif manusia? Sejumlah gagasan teoretis membahas hubungan antara terpaan pada kekerasan yang dimediasi dan agresi penonton. McGuire (1986) mencatat sejumlah teori yang dibaginya menjadi beberapa kategori. Ada kategori teori kausal (causal) yang memprediksikan bahwa terpaan akan memengaruhi keagresifan. Yang lain adalah teori-teori pembalikan kausal (causal reverse), menggambarkan alasan-alasan bahwa keagresifan dapat memengaruhi terpaan. Dalam kategori-kategori ini, teori-teori dapat dibagi lebih lanjut menjadi teori-teori positif dan negatif. Teori-teori positif memprediksikan bahwa terpaan dan agresi berkorelasi secara positif (misalnya, ketika salah satu variabel tinggi, yang lain juga demikian); teori-teori negatif memprediksikan hubungan-hubungan negatif di antara keduanya (misalnya, ketika salah satu variabel tinggi, yang lain cenderung menurun). Satu hal yang harus diingat, fakta bahwa terpaan mungkin meningkatkan agresi dalam sebuah adegan tidak berarti bahwa agresi tersebut juga tidak dapat meningkatkan terpaan dalam adegan yang sama, atau bahwa terpaan tidak mereduksi agresi dalam adegan lain. Semua teori ini dapat diterapkan dalam konteks-konteks yang berbeda-beda.

Perspektif menyangkut dampak kekerasan, seperti diuraikan dalam beberapa teori sebelumnya, bertitik tolak dari paradigma positivisme yang banyak diperdebatkan, karena dipandang terlalu menggeneralisasi dan 
menyederhanakan efek berantai sebab-akibat. Namun, sesungguhnya, penggunaan perspektif lain dalam mempersoalkan kekerasan di media juga memperlihatkan adanya dampak dalam skala tertentu. Hasil penelitian Sunarto $(2007 ;$ 2009) yang mempersoalkan tindak kekerasan personal dan struktural tertentu terhadap kaum wanita dalam program anak-anak produksi asing dan lokal memberi implikasi adanya naturalisasi atau pengalamiahan terhadap faktor-faktor kekerasan yang tertanam di benak khalayak belia. "Akibat naturalisasi ersebut, kita tidak mampu lagi mengenali kekerasan sebagai kekerasan, tetapi (menerimanya) sebagai suatu keniscayaan kulturl belaka" (Darmastuti \& J unaedi, 2012: 127).

\section{Mendefinisikan Kekerasan: Sebuah Persoalan}

Apa sesungguhnya definisi 'kekerasan'?

Lardellier (2003:18) menyatakan, kekerasan bisa didefinisikan sebagai prinsip tindakan yang mendasarkan diri pada kekuatan untuk memaksa pihak lain tanpa persetujuan (Haryatmoko, 2006:119). Di dalam kekerasan terkandung unsur dominasi yang mewujud dalam pelbagai bentuk: fisik, verbal, moral, psikologis, atau melalui gambar. Teorisi lain, Francois Chirpaz mendefinisikan kekerasan sebagai “... kekuatan yang sedemikian rupa dan tanpa aturan yang memukul dan melukai baik jiwa maupun badan, kekerasan juga mematikan entah dengan memisahkan orang dari kehidupannya, atau dengan menghancurkan dasar kehidupannya. Melalui penderitaan atau kesengsaraan yang diakibatkannya, kekersan tampak sebagai representasi kejahatan yang diderita manusia, tetapi bisa juga ia lakukan terhadap orang lain" (2000: 226, ibid.). Gerbner mendefinisikan violence sebagai "... the overt expression of physical force against others or self, or the compelling of action against one's will on pain of being hurt or killed' (Zillmann, 2002: 271). Dalam ranah kajian media, kekerasan media (media violence) didefinisikan sebagai “... media depictions on violence or aggression behavior (penggambaran media terhadap kekerasan atau perilaku agresi)."

Apapun definisi kekerasan, baik berdimensi partisipatif (melibatkan relasi pelaku dan korban), mau pun berdimensi tunggal (tidak melibatkan relasi pelaku dan korban), kekerasan berdampak melukai secara fisik maupun batiniah (Astuti, 2007: 14). Kekerasan sendiri, di media, tampil dalam banyak wujud. Anatomi kekerasan di media dapat terlihat pada Tabel 1.

Dalam praktiknya, kekerasan menjadi sebuah pertunjukan di arena media. Kekerasan sekaligus menjadi wahana untuk menyampaikan realitas dalam berbagai dunia yang coba ditransfer melalui bentuk-bentuk simbolik di media.

Kekerasan dokumen merupakan bagian dari dunia riil atau realitas objektif faktual yang direpresentasikan oleh media. Kekerasan fiksi merupakan bagian dari fiksi, fantasi, imajinasi yang ditampilkan oleh media. Sementara kekerasan simulasi merupakan pendakuan imajinasi kekerasan yang melibatkan khalayak untuk memasuki struktur sebuah permainan tertentu ( $\mathrm{Nel}$, dalam Haryatmoko, 2007: 127). Berdasarkan kategorisasi ini, menjadi jelas bahwa karya jurnalistik bernuansa kekerasan beresiko tergolong dalam kekerasan dokumen.

Kekerasan dokumen merupakan penampilan gambar kekerasan yang dipahami pemirsa atau pembaca dengan mata telanjang sebagai dokumentasi atau rekaman fakta kekerasan di media-apakah itu ditampilkan dalam isinya (lewat tindakan pembunuhan, pertengkaran, penusukan), atau dalam situasinya (konflik, kecelakaan, peristiwa kriminal), dan lain-lain (Haryatmoko, 2007: 128). Sebagaimana kita ketahui bersama, pemberitaan bukan sematamata masalah mentransfer informasi. Pemberitaan adalah juga teknik presentasi di mana hubungan antara pemirsa dan gambar ditata sangat teliti guna menampilkan realitas sedemikian rupa hingga mencapai tingkat dampak yang diinginkan. Ada berbagai teknik presentasi yang bisa digunakan-paling tidak, monstrasi, spektakularisasi, dan dramatisasi. Kekerasan dokumen terjadi acap bukan pada isinya, melainkan pada teknik presentasi ini (Haryatmoko, 2007:128).

Dengan begitu banyak kajian riset yang meyakinkan, serta bukti-bukti empiris perihal tindak kekerasan dalam kehidupan sehari-hari yang dipicu oleh terpaan kekerasan di media, mengapa masih sulit juga menerapkan aturan tegas seputar kekerasan di media?

\section{Rezim Kekerasan di Media: Argumen, Counter-Argument, dan Upaya Regulasi}

Tidak bisa dipungkiri, media sebagai representasi industri budaya senantiasa berada dalam tarik-menarik antara kepentingan bisnis/ industri/ekonomi, politik, dan publik. Program kreatif dan mendidik selalu dianggap mahal, sulit diproduksi, sudah begitu, tidak laku. Televisi sendiri, dalam temuan Williams, sudah telanjur menganggap bahwa kekerasan itu sangat menarik, menggairahkan untuk divisualisasikan (Wiliams, 2009: 170). Exciting. Maka, guna membenarkan dalih bahwa produk yang bermuatan kekerasan tersebut halal dan maslahat bagi kepentingan publik, berbagai argumentasi pun lantas dikembangkan oleh televisi.

Pertama, televisi mengembangkan dan 
secara konsisten mempromosikan argumen keberadaan dirinya sebagai mirror of society. Dalihnya, apa yang mereka representasikan adalah cermin realitas di tengah masyarakat. Dengan mencomot sekeping model realitas faktual, televisi lantas menggeneralisasikan, mengkonstruksi, membumbui, mendramatisasi, dan membuatnya seolah-olah merupakan hal yang paling penting, paling signifikan, dan ini yang berbahaya-paling alamiah! Padahal, tidak ada yang lebih alamiah selain potret besar masyarakat itu sendiri, bukan sepotong kecil realitas yang lantas disulap dan disimulasikan secara simbolik melalui tayangan televisi.

Kedua, televisi melarikan diri pada argumen kebebasan mengemukakan pendapat sebagai bagian dari hak asasi manusia. Ketika representasi kekerasan mulai dipertanyakan, apalagi di dalam pemberitaan, dengan enteng televisi membawabawa ideologi dasar keberadaan media, bahwa mereka adalah representasi demokrasi dengan membawa suara rakyat, bahwa mereka mengemban tugas sakral demokrasi untuk menjadi penyambung lidah rakyat, bahwa atas nama pembelaan hak asasi manusia, media tidak boleh dibungkam karena pembungkaman media berarti pelanggaran atas hak asasi manusia.

Argumen seperti ini harus dilawan dengan kenyataan bahwa kebebasan menyampaikan pendapat tidak bisa semaunya, tetapi harus diimbangi dengan pemahaman bahwa tidak semua pendapat, atau informasi, layak untuk dipromosikan dan dibela. Suara minoritas yang meminta hak politiknya ditegakkan, seperti suara kaum buruh yang terjepit UMR-nya, layak dibela demi harkat dan martabat manusia. Tetapi, hak politik macam apa yang mau dibela dari tokoh istri kesatu, kedua, dan ketiga yang mendzhalimi istri keempat? Hak kemanusiaan macam apa yang mau dibela dari seorang suami yang menderita lahirbathin gara-gara keempat isterinya saling berseteru satu sama lain? Hak kebebasan

\section{Tabel 1 \\ Anatomi Kekerasan di Media}

\begin{tabular}{|c|c|c|}
\hline Variabel & Dimensi & Operasionalisasi \\
\hline \multirow{8}{*}{$\begin{array}{l}\text { Bentuk } \\
\text { Kekerasan } \\
\text { (Sunarto, } \\
2007 \text { dan } \\
\text { Astuti, } \\
\text { 2007) }\end{array}$} & Fisik & $\begin{array}{l}\text { Kekerasan yg dilakukan oleh pelaku terhadap korban dgn cara memukul, menampar, } \\
\text { mencekik, menendang, melempar barang ke tubuh, menginjak, melukai dgn tangan } \\
\text { kosong, atau dengan alat/senjata, menganiaya, membunuh, serta perbuatan lain } \\
\text { yang relevan. }\end{array}$ \\
\hline & Psikologis & $\begin{array}{l}\text { Kekerasan yang dilakukan oleh pelaku terhadap mental korban dengan cara } \\
\text { membentak, menyumpah, mengancam, merendahkan, memerintah, melecehkan, } \\
\text { menguntit dan memata-matai atau tindakan lain yang menimbulkan rasa takut. }\end{array}$ \\
\hline & Seksual & $\begin{array}{l}\text { Tindakan yang mengarah pada desakan seksual seperti menyentuh, meraba, } \\
\text { mencium, atau melakukan tindakan yang tidak dikehendaki korban, ucapan-ucapan } \\
\text { yang merendahkan dan melecehkan, dengan mengarah pada aspek jenis kelamin, } \\
\text { memaksa hubungan seks tanpa persetujuan korban, memaksa melakukan aktivitas } \\
\text { seksual yang tidak dikehendaki, pornografi, kawin paksa. }\end{array}$ \\
\hline & Finansial & $\begin{array}{l}\text { Mencuri uang korban, menahan atau tidak memberi pemenuhan kebutuhan finansial } \\
\text { korban, mengendalikan dan mengawasi pengeluaran uang sampai sekecil-kecilnya. }\end{array}$ \\
\hline & Spiritual & $\begin{array}{l}\text { Merendahkan keyakinan dan kepercayaan korban, memaksa korban untuk meyakini } \\
\text { hal-hal yang tidak diyakininya, memaksa korban untuk mempraktikkan ritual dan } \\
\text { keyakinan tertentu. }\end{array}$ \\
\hline & Fungsional & $\begin{array}{l}\text { Memaksa melakukan sesuatu yang tidak sesuai dengan keinginan, menghalangi atau } \\
\text { menghambat aktivitas pekerjaan tertentu, memaksa kehadiran tanpa dikehendaki, } \\
\text { membantu tanpa dikehendaki, dll yang tidak relevan. }\end{array}$ \\
\hline & Relasional & $\begin{array}{l}\text { Kekerasan yang berakibat negatif pada hubungan antar personaL/hubungan sosial di } \\
\text { tengah masyarakat: menggunjingkan, mempermalukan, menggencet (bullying), } \\
\text { memusuhi, melalaikan tanggung jawab, mengutamakan kepentingan diri sendiri. }\end{array}$ \\
\hline & Pelaku & Tokoh yg melakukan kekerasan terhadap tokoh lain. \\
\hline \multirow{2}{*}{$\begin{array}{l}\text { Partisipasi } \\
\text { kekerasan }\end{array}$} & Korban & Tokoh yang mengalami penderitaan karena tindak kekerasan tertentu. \\
\hline & Sengaja & $\begin{array}{l}\text { Kekerasan yang disertai maksud dalam diri pelaku yang dinyatakan secara verbal atau } \\
\text { visual. }\end{array}$ \\
\hline \multirow[t]{2}{*}{$\begin{array}{l}\text { Motif } \\
\text { kekerasan }\end{array}$} & Tidak sengaja & $\begin{array}{l}\text { Kekerasan yang tanpa disertai maksud dalam diri pelakunya, tetapi tetap memberikan } \\
\text { efek penderitaan. Misalnya, gurauan yang berakibat kesakitan, hanya ikut-ikutan, } \\
\text { membela diri dari aksi kekerasan. }\end{array}$ \\
\hline & Verbal & $\begin{array}{l}\text { Kekerasan yang dilakukan dengan menggunakan kata-kata yang diucapkan dan } \\
\text { ditulis, berupa memaki, menyindir, sumpah serapah, mengancam, mengeluarkan kata- } \\
\text { kata kasar. }\end{array}$ \\
\hline \multirow[t]{2}{*}{$\begin{array}{l}\text { Ekspresi } \\
\text { kekerasan }\end{array}$} & Non verbal; & $\begin{array}{l}\text { Kekerasan yang dilakukan dengan menggunakan tindakan secara langsung, mis. } \\
\text { Memukul, menendang, menampar, mendorong, menjambak, memperkosa, membunuh, } \\
\text { menodong, memalak, mencekik, melempar, dijedotin, bullying, dll. }\end{array}$ \\
\hline & Gabungan & Gabungan kekerasan verbal dan nonverbal. \\
\hline
\end{tabular}


berpendapat macam apa yang mau diadvokasikan dari pemberitaan yang mengekspos kekerasan baik dalam isi maupun kemasannya?

Ketiga, televisi menggunakan dalih estetika, yaitu kebebasan berekspresi. Dalam konteks ini, kekerasan dalam televisi sebagai sebentuk ekspresi seni mencari pembenarannya pada tiga bentuk kekerasan estetik: horor regresif, horortransgresif, dan gambar simbol ( Nel dalam Haryatmoko, 2003:122-123). Horor regresif mengarahkan pada kekerasan yang riil namun ekstrem dan menyimpang sehingga citranya dieksploitasi habis-habisan. Misalnya, pada kasus Sumanto sang kanibal, media berulangkali mengekspos praktik kanibalisasinya secara visual, dan tidak mengimbanginya dengan edukasi masyarakat seputar krisis sosiopsikologis. Horor transgresif menampilkan kekerasan dalam konfigurasi seni yang baru dengan sentuhan menononjol pada apa yang belum dieksplorasi, yang terlarang, yang terkutuk, yang tabu. Misalnya, mengekspos habis-habisan film Hannibal, foto kekerasan tawanan perang Irak, citra korban mutilasi, dan lain-lain. Gambar simbol mencoba mengalamiahkan kekerasan dengan cara mengganti konteks kekerasan dengan tatanan yang lebih manusiawi dan dapat ditolerir sehingga akhirnya malah menjadi indah. Kekerasan dilembutkan dengan sedemikian rupa untuk mencari pembenaran bagi 'sang algojo'. Biasanya, kekerasan psikologis dan kekerasan verbal termasuk dalam kategori ini, terselip dalam drama sinetron hingga komedi yang memerintahkan kita untuk menertawakan kekurangan orang lain. Film laga yang penuh kekerasan diberi argumentasi bahwa penonton mendapatkan pembelajaran yang baik ketika sang hero menjadi pemenang-bahwa kebenaran akan mengalahkan kebatilan. Dalih ini digunakan untuk menutupi kenyataan bahwa kemenangan hanya bisa diraih melalui tindak kekerasan, dan bahwa kemenanganlah satusatunya tujuan dalam hidup. Untuk karya jurnalistik, pembenarannya biasanya menggunakan faktor realisme sifat kisah dan mendetailnya logika representasi (it's real! Based on factual events, etc.). Oh, ya, ngomongngomong, dalih estetika juga kerap dipakai untuk membenarkan argumen media bahwa keberadaan mereka adalah untuk menginformasikan dan menghibur masyarakat, sebagai katarsis, bukan untuk menambah stres publik.

Dalil semacam ini perlu dilawan dengan argumentasi bahwa kebebasan berekspresi secara estetis harus menimbang banyak hal, salah satunya adalah pentingnya memberi perlindungan pada pihak-pihak tertentu, seperti anak-anak. Televisi biasanya menjawab counter argument ini dengan mengaburkan substansi permasalahan. Mereka menantang regulator untuk membuat batas-batas ekspresi kekerasan secara estetis. Pembatasan ekspresi apapun secara estetis sesungguhnya memang memang sulit dilakukan. Namun, bukan berarti semua lantas bisa diekspresikan semenamena. Bagaimanapun, ada kerangka normatif untuk membatasi ekspresi estetis, yaitu norma budaya masyarakat sendiri. Jika media telah membenarkan tayangan kekerasan, itu berarti mereka dengan sembrono telah menganggap kekerasan adalah bagian dari norma yang ditolerir oleh budaya tempatnya bernaung. Untuk karya jurnalistik, media biasanya berargumen bahwa karya jurnalistik bersifat dokumentatif faktual, bukan karya fiksi-imajinatif, sehingga estetika tidak dibicarakan di sini. Salah besar. Estetika melekat pada karya apapun yang merepresentasikan realitas. Pada pemberitaan, estetika bukan semata-mata memilih dan merangkai kata, tetapi juga capturing image, mentransfer realitas dengan bahasa kamera atau sinematik, dan siapa bilang kalau itu bukan persoalan estetis?

Keempat, televisi menggunakan dalih khalayak aktif untuk menopang dalih estetika. Bunyi argumentasinya kira-kira begini: Kenapa media harus diatur-atur dan diregulasi? Supaya isinya tidak mempengaruhi masyarakat? Kalau begitu, sama saja dengan menganggap bahwa khalayak itu bodoh dan bisa dipengaruhi dengan gampang. Padahal, khalayak tidak bodoh, tidak pasif, mereka aktif mencerna informasi dan mampu membedakan yang baik dan yang jelek. Khalayak tidak senaif itu. Kalau selama ini khalayak ternyata memang mudah dipengaruhi, dan tidak cerdas berhadapan dengan media, maka, kemana saja itu sekolah, kyai, orangtua, dan para pendidik lain? Adalah tugas mereka untuk mendidik masyarakat, bukan tugas media yang tugasnya adalah mewartakan realitas. Begitulah ungkapan media.

Pernyataan ini perlu dilawan dengan argumentasi bahwa tidak semua khalayak bersifat aktif. Ada kelompok khalayak yang memang tidak aktif atau belum aktif, dan mereka perlu dilindungi. Sebelumnya diterjunkan pada tanah tak bertuan (jika maunya media seperti itu), khalayak ini perlu dididik. Dan, dalam konteks media literacy, menanamkan sikap kritis terhadap media bukan cuma tugas para pendidik profesional saja. Adalah tugas media juga untuk mengedukasi publik seputar tayangan yang baik dan buruk. Media harus bekerjasama dengan pranata sosial lainnya untuk menciptakan generasi yang cerdas dan bermoral. Seperti kata Hillary Clinton, "it takes a village to raise a child"-maka, kontribusi macam apakah yang diberikan oleh media untuk mendidik khalayak jika tayangan yang ditampilkan sarat dengan unsur kekerasan? Bandura, dalam teori Social Learning menyatakan bahwa media di era sekarang merupakan 'guru' yang menyosialisasikan norma-norma sebagai warga negara atau anggota 
masyarakat kepada publik. Khalayak belajar tentang lingkungannya bukan melalui interaksi langsung, melainkan dimediasi oleh media. Mediasi akan berbahaya jika lingkungan yang diwartakan melulu tampil melalui representasi kekerasan.

Kelima, dalih ekologi. Pertama-tama, media seperti televisi tidak mau disalahkan sebagai kontributor penyebab rusaknya masyarakat atau kehidupan anak akibat muatan kekerasan dalam produk-produk media. Maka televisi pun merujuk pada faktor-faktor lingkungan yang sudah dari sananya memang penuh dengan kekerasan. Atau menyalahkan budaya. Atau mengandalkan argumen antropologis: di Madura, merokok adalah perilaku kultural sehingga menampilkan tayangan anak-anak sedang merokok di Madura itu adalah hal yang biasa. Menganggapnya sebagai bentuk kekerasan, atau penyimpangan, berarti menghina realitas budaya orang Madura, tutur media. Contoh lain: balas dendam ala mafia yang disebut-sebut sebagai kulturnya orang Sisilia. Atau, potong tangan buat pencuri yang dinyatakan sebagai ajaran agama tertentu. Semua ini merupakan materi pemberitaan yang sering dieksploitasi kekerasannya tanpa menimbang konteksnya.

Pada wilayah argumentasi ini, biasanya, media meminta bukti empiris atau hasil kajian yang menunjukkan bahwa medialah satu-satunya variabel, atau faktor paling signifikan yang menyebabkan muncul perilaku agresif, atau sikap menyimpang khalayaknya. Perdebatan yang memasuki wilayah riset ini bahkan niscaya melangkah lebih jauh lagi: mempersoalkan masalah validitas dan reliabilitas riset, sehingga mengaburkan esensi permasalahannya. Dalih seperti ini perlu dilawan dengan memberikan argumen sosiologis-organik: bahwa media adalah bagian dari masyarakat, bagian dari komunitas budaya. Pertanyaannya, apakah media mau membenarkan diri menjadi bagian dari kultur kekerasan-kalaupun itu merupakan bagian dari budayanya dan situasinya saat ini?

Keenam, dalih imajinasi individual. Bahwa kekerasan itu hanya perasaan segelintir orang yang lalu dibesar-besarkan dan digeneralisasi menjadi persoalan publik. Media biasanya mengecam sensitivitas berlebihan dari para pengkritik kekerasan dan mencoba memperlihatkan buktibukti bahwa 'akibatnya tidak seserius itu, kok!'. Kalaupun ada yang berperilaku menyimpang, itu karena dari sononya memang sudah begitu. Memang sudah psikopat!

Dalih seperti ini perlu dilawan dengan argumentasi yangmemperlihatkan bahwa kesadaran yang dimunculkan media adalah kesadaran kolektif-gunakan logika distribusi. Masalah penyimpangan individu? Media memang bukan satu-satunya penyebab, mungkin juga bukan penyebab utama. Tapi media punya kontribusi dalam memicu ledakannya. Atau, minimal, media meneguhkan gejala yang sudah ada sebelumnya. Dalam situasi adanya psikopat yang tak bisa dikenali gejalanya berkeliaran di tengah masyarakat, apakah media mau jadi pemantik api? Atau, sekalian saja jadi penyiram bensin?

Ketujuh, dalih kepentingan publik. Ujungujungnya, media melarikan persoalan pada tayangan jurnalistiknya dengan argumen public interest-bahwa tayangannya sebenarnya untuk kepentingan publik, punya maksud baik, hanya saja persoalannya terletak pada kemasannya, sehingga cukup kemasannya saja yang diperbaiki, substansi isinya toh sebenarnya penting. Bagaimanapun media telah menempuh resiko untuk meliput berita ini karena tantangan lapangannya tidak sedikit (maksud sebenarnya, media hanya ingin diapresiasi, biar sedikit. Bagaimanapun, apresiasi ini menurut mereka layak diberikan berhubung dalam memproduksi tayangan, ada harga atau ongkos yang harus dibayar).

Dalih seperti ini perlu disikapi dengan hatihati, karena tergolong pada questions of authorship dan aesthetic value. Di Inggris yang terkenal konservatif pun, dalih tersebut bisa menjungkalkan Undang-Undang yang galak macam "Obscene Publication Act".

The Obscene Publication Act defines obscenity as something whose effect as a whole is to 'tend to deprave and corrupt persons who are likely, having regard to all relevantcurcumstances, to read, see, or hear the matter contained or embodied therein'. For the act, a programme might be considered obscene because of what is represented, but it can be legal because the intention and effect of the whole work is artistically excellent or morally improving. (Bignell, 2004:245)

Mari kita ambil contoh tayangan bencana. Ilustrasi atau visualisasi bencana di pemberitaan televisi yang menampakkan kesengsaraan itu memang bikin miris dan menjaring banyak sumbangan. Masalahnya, apa tidak ada sudut pandang lain? Televisi atau media yang mengekspos bencana, perlu sesungguhnya mempertimbangkan perasaan atau dampak lanjutan dari kondisi korban yang diekspos sedemikian rupa, atau derita dan luka keluarga korban maupun keluarga pelaku. Dalih demi kepentingan yang lebih besar, tidak bisa diterima dengan mengorbankan kepentingan pihak lain yang jumlahnya minoritas. Hitung-hitungan pragmatisme yang berpijak pada filosofi Utilitarianisme juga punya pertimbangan yang serius. Ini masalah kemiskinan kreativitas televisi/ media saja sebenarnya. Berpihak pada kepentingan publik-kah? Publik yang mana dulu?

Dalam membuat regulasi, hal-hal lain juga perlu menjadi pertimbangan. Saya memberi penguatan pada apa yang tentunya sudah 
berulangkali dibahas. Pertama, menentukan batas. Jangan ragu menetapkan pembatasan. Tentu, pembatasan harus cerdas dan manusiawi. Untuk itu, terkait dengan tayangan kekerasan dalam pemberitaan jurnalistik di televisi, regulasi harus mempertimbangkan berbagai dimensi.

Dimensi persepsi, masalahnya terumus dalam pertanyaan sejauhmana terkait dengan visual, pendengaran dan interaktif. Jadi, regulator perlu menentukan sejahmana batas tidak dapat dipresentasikan, dilihat, didengar, atau disentuh. Kedua, dari dimensi afeksi, sejauhmana kekerasan di media bisa menyebabkan traumatisme, kekacauan kepribadian, stres, kegelisahan dan rasa malu. Ketiga, dari dimensi estetika, bisakah ditentukan ukuran mana yang indah mana yang jelek atau kumuh. Keempat, dari dimensi m o ral dan keyakinan, mana yang bisa dipercaya, mana yang berpengaruh jahat. (Haryatmoko, 2007: 127)

Kedua, visualisasi atau representasi kekerasan tidak secara langsung. J ika representasi langsung yang menjadi masalahnya, maka regulasi juga perlu menimbang strategi yang mungkin digunakan oleh produser tayangan untuk mengakalinya. Perlu dipertimbangkan sejauhmana blurred pictures, label kategorisasi tayangan, pemindahan jam tayang, maupun graphic illustration diperbolehkan mewakili realitas yang ingin ditampilkan.

Ketiga, regulasi bagaimanapun bukan untuk merepresi media. Maka regulator juga perlu berupaya mengedukasi media agar memahami bahwa tujuan pengaturan dan pembatasan sebenarnya diarahkan pada penciptaan atmosfer yang sama-sama sehat, dan bahwa baik media, industri, negara dan khalayak akan sama-sama merasakan manfaatnya jika media tertata dengan baik. Tekankan bahwa regulasi melindungi media agar tidak dijadikan kepentingan politis atau arena kontestasi pihak-pihak lain.

Regulasi juga bisa melindungi media dari kekerasan yang dilakukan oleh sekelompok khalayak atas nama anasir- anasir kepentingan tertentu. Dalam konteks ini, adalah penting bagi regulator untuk mem-promosikan program yang bagus, memberikan reward, menunjukkan roadmap besar dari pemberlakuan undang-undang dan indikator pengujian efektivitas undang-undang serta cara mengukurnya, program-program terencana secara berkala untuk mengedukasi semua stakeholder, agenda monev, pelibatan masyarakat sebagai stakeholder utama, dan bentuk-bentuk apresiasi lainnya. Cara ini biasanya dapat meredam sekaligus menetralisir resistensi media terhadap regulasi yang dikenakan bagi mereka.

\section{Simpulan dan Saran}

Berbicara tentang kekerasan di media, memang sampai kapanpun tidak akan ada habisnya. Tetapi memerangi kekerasan dengan kekerasan, sama saja dengan mereplikasi kekerasan itu sendiri. Inilah dasar mengapa regulasi diperlukan-agar siapapun tahu bahwa kekerasan tidak bisa didiamkan, agar kita semua mampu belajar mengelola kekerasan tanpa harus mengerasi pihak manapun. Melihat pemberitaan televisi, sesungguhnya bak memandang diri kita sendiri, tetangga-tetangga, anak-anak, orangtua kita, teman-teman, lingkungan tempat kita tumbuh, hidup, berkembang, bernapas. It's us that matters. Us.

\section{Daftar Pustaka}

Astuti, S.I. (2007). Kekerasan dan Mistik dalam Sinetron Religius. Bandung: LPPM Unisba.

Bignell, J. (2004). An Introduction to Television Studies. New York: Routledge.

Chen, M. (2005). Mendampingi Anak Menonton Televisi. Jakarta: Gramedia.

Haryatmoko. (2007). Etika Komunikasi: Manipulasi Media, Kekerasan, dan Pornografi. Jogja: Kanisius.

Mulkan, D. (2011). Pemahaman dan Penerapan Kode Etik Jurnalistik dan Kode Etik Penyiaran dalam Program Berita di Metro TV dan TV One. Disertasi. Bandung: Universitas Padjadjaran.

Panjaitan., Iqbal., Erica, L., dan Dhani, T.M (2006). Matinya Rating Televisi: I/usi Sebuah Netralitas. Jakarta: Buku Obor.

Perry, D.K. (2002). Theory and Research in Mass Communication: Contexts and Consequences (2nd Ed.). LEA: Mahwah, New Jersey.

Sunarto (2012). Literasi Media dan Dominasi Maskulin di Televisi. Dalam Darmastuti, Rini dan Junaedi, Fajar. Literasi Media dan Kearifan Lokal: Konsep dan Aplikasi. Salatiga: UKSW dan ASPIKOM, hal. 126-141.

Susanti, D. (2011). Sekolah Kriminal di Televisi. Dalam Junaedi, Fajar (ed.). Mesin Pencuci Otak: Menggugat Tayangan Televisi Indonesia. Jogja: UMY dan ASPIKOM.

Williams, R. (2009). Televisi (diterjemahkan oleh Dian Yanuardy). Jogjakarta: Resist Book.

Zillman, D., and Bryant, J. (2002). Media Effects: Advances in Theory and Research. New York: Routledge. 